\title{
Effect of Sex Hormones on Serum Levels of Nesfatin-1 in Experimental Rats
}

\author{
MAHER N. IBRAHIM, M.D.; KAMELIA I. ATTIA, M.D.; MARWA A. HABIB, M.D. and \\ DALIA A. ROSHDY, M.Sc.
}

The Department of Physiology, Faculty of Medicine, Zagazig University

\begin{abstract}
Background: Nesfatin-1 is nucleobindin 2-derived polypeptide involved in feeding regulation. The expression of Nesfatin-1 in the hypothalamus, pituitary gland and reproductive organs drew the attention to its potential role in regulation of hypothalamic-pituitary-gonadal axis. Yet, very few data are available regarding the effect of gonadal hormones on the regulation of Nesfatin-1.

Aim of Study: The present study was designed to explore the probable sex difference in serum Nesfatin-1 levels and the relationship between serum levels of sex hormones and Nesfatin-1 in adult male and female albino rats.

Material and Methods: The study involved 18 male and 30 female albino rats. The male rats were divided in to three equal groups: Control (M Cont.), orchidectomized (ORX), and testosterone-treated orchidectomized (T-treated ORX). The female rats were divided in to five equal groups: Control (F Cont.), ovariectomized (OVX), estradiol-treated ovariectomized (E-treated OVX), progesterone-treated ovariectomized (P-treated OVX), and estradiol and progesterone-treated ovariectomized (E + P-treated OVX). Serum levels of Nesfatin$1, \mathrm{LH}$ (in all rats), testosterone (in male rats), estradiol and progesterone (in female rats) were measured.

Results: Serum levels of Nesfatin-1 were higher in female than in male control rats. Nesfatin-1 levels significantly decreased in ORX group compared with M Cont. group and increased in T-treated ORX group compared with ORX group. Nesfatin-1 positively correlated with testosterone in ORX and T-treated ORX groups, but insignificantly correlated with LH in all groups. Serum levels of Nesfatin-1 were significantly decreased in OVX group compared with F Cont. group and increased in E-treated OVX, P-treated OVX and In E + Ptreated OVX groups when compared with those of OVX group. Positive correlations were found between Nesfatin-1 and both estradiol and progesterone in OVX, E-treated OVX, P-treated OVX, and E+P-treated OVX groups; however, no significant correlations were found with LH in all groups.
\end{abstract}

Conclusion: From the above results it can be concluded that gonadal hormones are important regulators of serum levels of Nesfatin-1 in albino rats.

Correspondence to: Dr. Marwa A. Habib, E-Mail: marwahabib2015@gmail.com
Key Words: Nesfatin-1 - Sex hormones - Hypothalamus Ovariectomy.

\section{Introduction}

NESFATIN-1 is an anorexigenic peptide consists of 82 amino acids and derived from the N-terminal region of a larger precursor protein, nucleobindin 2 (NUCB2) [1]. The expression of NUCB2 / Nesfatin-1 was demonstrated centrally within the hypothalamus and other brain regions involved in the regulation of feeding, stress modulation, locomotion, thermogenesis and reproduction [2,3] . Additionally, Nesfatin-1 expression was detected peripherally in the digestive organs $[4,5]$, the adipose tissues [6] and the heart [7]. Nesfatin-1 was supposed to play a role in the regulation of anxiety, sleeping, gastric acid secretion and emptying, glucose metabolism and insulin secretion [8]

Nesfatin-1 expression was detected in the male reproductive organs of human and rodents including the Leydig cells, the testis, and the epididymis; and was suggested to regulate steroidogenesis and spermatogenesis by local signaling during development and under metabolic stress [9-11]. As regard the female reproductive system, Nesfatin-1 expression in the ovary was localized in the theca cells, interstitial cells, and some of the oocytes, and in the uterus on the epithelial cells of the endometrium and uterine glands $[\mathbf{1 2 , 1 3 ]}$.

Nesfatin-1 was suggested to be involved in the regulation of reproductive maturation and function through modulating the hypothalamic-pituitarygonadal axis [14] . García-Galiano et al., reported that NUCB2 mRNA and protein levels increased in the hypothalamus during the pubertal transition 
of female rats. Also, they found that intracerebroventricular injection of Nesfatin-1 induced significant elevation in circulating Lutenizing Hormone (LH) levels [9]. In contrast, Gonzalez et al., found that a single intraperitoneal injection of synthetic goldfish Nesfatin-1 resulted in an acute decrease in the expression of hypothalamic Gonadotrophin Releasing Hormone (GnRH) and serum LH levels [15]. Despite the previous studies that demonstrated the expression of Nesfatin- 1 in the reproductive system, it is not clear yet the function of Nesfatin1 in the reproductive organs. Also, the relationship between Nesfatin- 1 and sex hormones is still a matter of controversy.

Therefore, the present study was designed to explore the potential sexual variation in serum levels of Nesfatin-1, the relationship between serum levels of sex hormones and Nesfatin- 1 and in turn the effect of orchidectomy and ovariectomy on serum levels of Nesfatin-1 in adult male and female albino rats respectively, and also to clarify the effect of sex hormones injection on serum levels of Nesfatin-1 in adult male and female albino rats.

\section{Material and Methods}

\section{Animals:}

In the period from 10th April to $28^{\text {th }}$ June 2015, the study was performed in the Animal House of Faculty of Medicine, Zagazig University and involved a total number of 48 healthy adult albino rats of local strain (18 males and 30 females) weighing $150-250 \mathrm{~g}$ that were obtained from the animal house. The female rats were separated from males to avoid conception and all rats were kept in steel wire cages ( 6 per cage) under hygienic conditions at comfortable room temperature with 12-hour light/dark cycles, received food and water ad libitum and fed the same diet that consisted of mixed commercial rat laboratory chow. The rats were accommodated to laboratory conditions for two weeks before the beginning of the experiments. The experimental procedures were approved by the Institutional Research Board and Ethics Committee of Faculty of Medicine, Zagazig University.

\section{Methods:}

After the adaptation period, the male rats were randomized and divided into 3 equal groups $(n=6)$ : Male control subgroup (M Cont.) that was injected Subcutaneously (SC) with sesame oil [ADWIC Laboratory Chemicals, Egypt] at a dose of 100 $\mathrm{t} 1 /$ rat; once daily for 3 successive days, orchidectomized subgroup (ORX) in which rats were bilat- erally orchidectomized and left for 48 hours after operation for healing then injected SC with sesame oil once daily for 3 successive days, and orchidectomized subgroup injected by Testosterone $(\mathrm{T})(\mathrm{T}$ treated ORX) in which orchidectomized rats were injected SC with testosterone [(Sustanon 100), Nile CO. for Pharmaceuticals-Cairo-A.R.E.] at a dose of $0.5 \mathrm{mg} / 100 \mathrm{~g}$ body weight (b.w.) in sesame oil twice daily for 3 successive days [16]

The female rats were randomized and divided into 5 equal groups $(n=6)$ : Female control group (F Cont.) that was injected SC with sesame oil at a dose of $100 \mathrm{Vra}$; once daily for 8 successive days, ovariectomized group (OVX) in which rats were bilaterally ovariectomized and left for 48 hours after operation for healing then injected SC with sesame oil once daily for 8 successive days, ovariectomized group injected by Estradiol (E) (Etreated OVX) in which each ovariectomized rat was injected SC with estradiol benzoate [(Folone5), Misr CO. pharm. Ind. S.A.A. Materia. CairoA.R.E.] at a dose of $4 \mathrm{mg} / \mathrm{kg}$ b.w. in sesame oil once daily for 8 successive days, ovariectomized group injected by Progesterone (P) (P-treated OVX) in which each ovariectomized rat was injected SC with progesterone [(Lutone), Misr CO. pharm. Ind. S.A.A. Materia. Cairo-A.R.E.] at a dose of $20 \mathrm{mg} / \mathrm{kg}$ b.w. in sesame oil once daily for 8 successive days, and ovariectomized group injected by estradiol and progesterone $(\mathrm{E}+\mathrm{P}$-treated $\mathrm{OVX})$ in which each ovariectomized rat was injected SC with estradiol benzoate $(4 \mathrm{mg} / \mathrm{kg}$ b.w.) and progesterone $(20 \mathrm{mg} / \mathrm{kg} \mathrm{b.w}$.) in sesame oil once daily for 8 successive days [17].

Sexual cycle determination in female rats: Vaginal secretions from the non-ovariectomized rats were collected with a plastic pipette filled with $10 \mathrm{~mL}$ of normal saline by inserting the tip into the rat vagina and then the unstained material was observed under a light microscope and cycles with duration of 4-5 days were considered regular according to Marcondes et al. [18]

\section{Gonadectomy technique:}

The overnight-fasted rat was anaesthetized intraperitoneally with pentobarbital sodium [(40 $\mathrm{mg} / \mathrm{kg}$ b.w.); Misr CO. pharm. Ind. S.A.A. Materia, Cairo-A.R.E.] then tied to the operating board where hair was removed from the lower abdomen and the bare area of the skin was sterilized by $70 \%$ ethyl alcohol. A midline incision was made through the skin and the abdominal wall. In male rats, orchidectomy was performed according to Fernan- 
dez-Guasti and Martinez-mota where the testes were explored and picked up by toothed forceps, a ligature of catgut was placed between the epididymis and testes, and then the testes were removed surgically [19]. In female rats, ovariectomy was performed according to Irahara et al., where the ovaries were explored and removed surgically [20] Then the viscera were replaced and the abdominal wall was repaired with catgut thread, then the skin incision was closed with sterile silk suture. Finally, garamycin cream was put over the closed incision and covered with sterilized gauze and the rat was observed until recovery from anesthesia.

\section{Blood sampling and laboratory assay:}

Blood samples were collected from nonovariectomized female rats in the afternoon of estrous day of their cycles after an overnight fasting to avoid circadian rhythm of serum hormonal levels. Blood samples were collected 24 hours after the end of treatment [21] to measure serum levels of Nesfatin- 1, LH levels in all groups, testosterone in male groups, and estradiol and progesterone in female groups. Blood samples were obtained by decapitation of rats under ether anesthesia. The blood was collected in clean plastic centrifuge tubes and allowed for clotting. Then serum was separated by centrifugation of blood 3000rpm for 15 minutes. The supernatant serum was pipette off using fine tipped automatic pipettes and stored in deep frozen at $-20^{\circ} \mathrm{C}$ until used for measurement of the following parameters:

Serum Nesfatin-1 levels: Using rat Nesfatin-1 ELISA Kits (Shanghai SunRed Biotechnology Company, China) according to Oh-I et al. [1] .

Serum testosterone, estradiol, progesterone and LH levels: Using rat ELISA kits; Catalogs Number BC-1115, BC-1111, BC-1113 and BC-1031 respectively (BioCheck Inc 323 Vintage Park Dr. Foster City, CA 94404) according to Tietz [22].

Statistical analysis: Values were presented as mean \pm SD. The statistical analysis was done using SPSS program (Version 19 for windows) (SPSS Inc. Chicago, IL, USA). Unpaired student's $t$-test: Was used for comparison of means of two variables in two different groups. One-way ANOVA, followed by LSD post hoc test was used for comparison of means of more than two different groups. Pearson's correlation ( $r$ ) was used to analyze correlations between serum levels of Nesfatin- 1 and the other measured parameters. $p$-value $<0.05$ was considered significant for all performed statistical tests.

\section{Results}

A slight statistically significant increase in serum levels of Nesfatin-1 was found in female control group when compared with those of male control group $(p<0.05)$. The mean values \pm SD were found to be $(7.73 \mathrm{~g} / \mathrm{ml} \pm 0.53$ and $7.02 \mathrm{ng} / \mathrm{ml}$ \pm 0.45 ) respectively.

\section{Studies on male albino rats (Table 1):}

A statistically significant reduction in serum levels of Nesfatin-1was found in ORX group when compared with those of M Cont. group $(p<0.001)$. In T-treated ORX group, there was a statistically significant increase in serum levels of Nesfatin-1 when compared with those of ORX group $(p<0.001)$ and a statistically insignificant change when compared with those of control group $(p>0.05)$.

As regard serum levels of testosterone, there was a statistically significant decrease in ORX group when compared with those of M Cont. group $(p<0.001)$, while, there was a statistically significant increase in T-treated ORX when compared with those of M Cont. and ORX groups $(p<0.001)$ Statistically significant positive correlations were found between serum levels of testosterone and serum levels of Nesfatin-1 in ORX and T-treated ORX groups while, they were insignificantly correlated in M Cont. group.

Concerning serum levels of $\mathrm{LH}$, there was a statistically significant increase in ORX group when compared with those of M Cont. group $(p<0.01)$. In T-treated ORX groups, serum levels of LH were significantly decreased when compared with those of ORX group $(p<0.05)$ and showed a statistically insignificant change when compared with those of M Cont. group ( $p>0.05)$. No statistically significant correlations were found between serum levels of Nesfatin-1 and LH in all male groups.

\section{Studies on female albino rats (Table 2):}

As regard serum levels of Nesfatin-1, they were significantly decreased in OVX group when compared with those of F Cont. group $(p<0.001)$. In E-treated OVX group, serum levels of Nesfatin-1 were significantly increased when compared with those of OVX group $(p<0.001)$, and showed a statistically insignificant change when compared with those of F Cont. group $(p>0.05)$ In P-treated OVX group, serum levels of Nesfatin-1 were significantly decreased when compared with those of F Cont. group $(p<0.01)$ and E-treated OVX group 
$(p<0.001)$ and significantly increased when compared with OVX group $(p<0.01)$. In $\mathrm{E}+\mathrm{P}$-treated OVX group, serum levels of Nesfatin-1 were significantly increased when compared with those of F Cont. group $(p<0.05)$, OVX group $(p<0.001)$ and P-treated OVX group $(p<0.001)$ and showed a statistically insignificant change when compared with those of E-treated OVX group $(p>0.05)$.

Regarding serum levels of estradiol, they were significantly decreased in OVX group when compared with those of F Cont. group $(p<0.001)$. In E-treated OVX group, serum levels of estradiol were significantly increased when compared with those of OVX group $(p<0.001)$ and showed a statistically insignificant change when compared with those of F Cont. group ( $p>0.05)$. In P-treated OVX group, serum levels of estradiol were significantly decreased when compared with F Cont. group $(p<0.001)$ and E-treated OVX group ( $p$ $<0.001)$ and showed a statistically insignificant change when compared with OVX group $(p>0.05)$. In E + P-treated OVX group, serum levels of estradiol were significantly increased when compared with those of F Cont. group ( $p<0.05)$, OVX group $(p<0.001)$ and $\mathrm{P}$-treated OVX group ( $p$ $<0.001)$ while, they showed a statistically insignificant change when compared with those of Etreated OVX group $(p>0.05)$. Statistically significant positive correlations were found between serum levels of estradiol and Nesfatin-1 in OVX, E-treated OVX, P-treated OVX and E + P-treated OVX groups; while, they were insignificantly correlated in F Cont. group.

Concerning serum levels of progesterone, they were significantly decreased in OVX group when compared with those of F Cont. group $(p<0.001)$. In E-treated OVX group, serum levels of progesterone were significantly decreased when compared with those of F Cont. group $(p<0.001)$ and showed a statistically insignificant change when compared with those of OVX group $(p>0.05)$. In P-treated OVX group, serum levels of progesterone were significantly increased when compared with those of OVX group $(p<0.001)$ and E-treated OVX group $(p<0.001)$, and showed a statistically insignificant change when compared with those of F Cont. group $(p>0.05)$. In E + P-treated OVX group, serum levels of progesterone were significantly increased when compared with those of OVX and E-treated OVX groups $(p<0.001)$; while, they showed a statistically insignificant change when compared with those of F Cont. and P-treated OVX groups $(p>0.05)$. Statistically insignificant correlations were found between serum levels of progesterone and Nesfatin-1 in F Cont. group; while, they were positively correlated in OVX, E-treated OVX, Ptreated OVX and E + P-treated OVX groups.

As regard serum levels of $\mathrm{LH}$, they were significantly increased in OVX group when compared with those of control group $(p<0.001)$. In E-treated OVX group, serum levels of LH were significantly decreased when compared with those of $\mathrm{F}$ Cont. group $(p<0.05)$ and OVX group $(p<0.001)$. In $\mathrm{P}$ treated OVX group, serum levels of LH were significantly decreased when compared with those of OVX group $(p<0.001)$; while, they showed a statistically insignificant change when compared with those of F Cont. and E-treated OVX groups $(p>0.05)$. In $\mathrm{E}+\mathrm{P}$-treated OVX group, serum levels of LH were significantly decreased when compared with those of F Cont. group $(p<0.05)$ and OVX group $(p<0.001)$; while, they showed a statistically insignificant change when compared with E-treated OVX and P-treated OVX groups $(p>0.05)$. No statistically significant correlations were found between serum levels of LH and Nesfatin-1 in all female groups.

Table (1): Comparison between the serum levels of measured parameters in male rats' groups.

\begin{tabular}{llll}
\hline Parameters & $\begin{array}{c}\text { Groups } \\
\text { group }\end{array}$ & \multicolumn{1}{c}{$\begin{array}{c}\text { ORX } \\
\text { group }\end{array}$} & $\begin{array}{c}\text { T-treated ORX } \\
\text { group }\end{array}$ \\
\hline Nesfatin-1 $(\mathrm{ng} / \mathrm{ml})$ & $7.02 \pm 0.45$ & $4.58 \pm 0.82 \mathbf{a}$ & $6.95 \pm 1.13 \mathbf{b}$ \\
Testosterone $(\mathrm{ng} / \mathrm{ml})$ & $3.14 \pm 0.62$ & $0.098 \pm 0.03 \mathbf{a}$ & $4.75 \pm 0.55 \mathbf{a}^{\mathbf{a}} \mathbf{b}$ \\
& $r=0.625, \mathrm{NS}$ & $r=0.860, p<0.05$ & $r=0.887, p<0.05$ \\
LH $(\mathbf{I} / \mathrm{ml})$ & $1.47 \pm 0.23$ & $1.99 \pm 0.31 \mathbf{a}$ & $1.56 \pm 0.21 \mathbf{b}$ \\
& $r=0.721, \mathrm{NS}$ & $r=0.484, \mathrm{NS}$ & $.033, \mathrm{NS}$ \\
\hline
\end{tabular}

Data are represented as mean \pm SD.

a : Significant versus M Cont. group.

b : Significant versus ORX group.

$r$ : Correlation with serum Nesfatin-1 levels.

NS : Non-Significant $(p>0.05)$ 
Table (2): Comparison between the serum levels of measured parameters in female rats' groups.

\begin{tabular}{|c|c|c|c|c|c|}
\hline Parameters & $\begin{array}{l}\text { F Cont. } \\
\text { group }\end{array}$ & $\begin{array}{l}\text { OVX } \\
\text { group }\end{array}$ & $\begin{array}{l}\text { E-treated OVX } \\
\text { group }\end{array}$ & $\begin{array}{l}\text { P-treated OVX } \\
\text { group }\end{array}$ & $\begin{array}{l}\text { E + P-treated } \\
\text { OVX group }\end{array}$ \\
\hline Nesfatin-1 (ng/ml) & $7.73 \pm 0.53$ & $4.30 \pm 0.68 \mathbf{a}$ & $8.73 \pm 0.79^{b}$ & $6.28 \pm 1.26^{\mathbf{a}^{\prime} \mathbf{b}^{\prime} \mathbf{c}}$ & $8.92 \pm 0.94 \mathbf{a}^{\mathbf{a}} \mathbf{b} \mathbf{d}^{\prime} \mathbf{d}$ \\
\hline Estradiol (pg/ml) & $\begin{array}{l}29.62 \pm 3.81 \\
r=0.602, \mathrm{NS}\end{array}$ & $\begin{array}{l}6.35 \pm 1.27 \mathbf{a} \\
r=0.861, p<0.05\end{array}$ & $\begin{array}{l}33.49 \pm 4.65^{\mathbf{b}} \\
r=0.936, p<0.01\end{array}$ & $\begin{array}{l}5.91 \pm 0.98 \mathbf{a} \mathbf{c}^{-} \\
r=0.975, p<0.01\end{array}$ & $\begin{array}{l}34.87 \pm 4.43^{\mathbf{a}^{\prime} \mathbf{b}^{\prime} \mathbf{d}} \\
r=0.949, p<0.01\end{array}$ \\
\hline Progesterone (ng/ml) & $\begin{array}{l}10.80 \pm 1.83 \\
r=0.285, \mathrm{NS}\end{array}$ & $\begin{array}{l}1.74 \pm 0.34 \mathrm{a} \\
r=0.968, p<0.01\end{array}$ & $\begin{array}{l}1.91 \pm 0.34 \mathbf{a} \\
r=0.913, p<0.05\end{array}$ & $\begin{array}{l}11.52 \pm 1.48^{\mathbf{b}} \mathbf{c} \\
r=0.957, p<0.01\end{array}$ & $\begin{array}{l}12.33 \pm 1.75 \mathbf{b}^{\prime} \mathbf{c} \\
r=0.968, p<0.01\end{array}$ \\
\hline LH (IU⿴囗十) & $\begin{array}{l}2.72 \pm 0.53 \\
r=-0.337, \mathrm{NS}\end{array}$ & $\begin{array}{l}3.78 \pm 0.52 \mathrm{a} \\
r=0.283, \mathrm{NS}\end{array}$ & $\begin{array}{l}2.17 \pm 0.39 \mathbf{a}^{\prime} \mathbf{b} \\
r=0.305, \mathrm{NS}\end{array}$ & $\begin{array}{l}2.37 \pm 0.39 \mathbf{b} \\
r=0.337, \mathrm{NS}\end{array}$ & $\begin{array}{l}2.06 \pm 0.34^{\mathbf{a}^{\prime} \mathbf{b}} \\
r=0.391, \mathrm{NS}\end{array}$ \\
\hline $\begin{array}{l}\text { Data are represented as m } \\
\text { a: Significant versus F C } \\
\text { b: Significant versus OV) } \\
\text { c: Significant versus E-tre }\end{array}$ & $\begin{array}{l}\text { oup. } \\
\text { up. } \\
\text { OVX group. }\end{array}$ & $\begin{array}{ll}\mathbf{d} & : \text { Signific } \\
r & : \text { Correlat } \\
\text { NS } & : \text { Non-Sig }\end{array}$ & $\begin{array}{l}\text { rsus P-treated O } \\
\text { ith serum Nesfat } \\
\text { ant }(p>0.05) \text {. }\end{array}$ & $\begin{array}{l}\text { up. } \\
\text { els. }\end{array}$ & \\
\hline
\end{tabular}

\section{Discussion}

The present study revealed a sex difference in serum levels of Nesfatin-1 as they were significantly increased in female control group when compared to male control group. This finding is consistent with the study by Hofmann et al., which demonstrated that the mean NUCB2/Nesfatin-1 levels were higher in females compared to male persons and this sexual difference was attributed to the variation in the number and distribution of Nesfatin- 1 receptors between male and female reproductive organs [23]. In contrast to these results, the study by Kim et al. demonstrated similar expression levels of Nesfatin-1/NUCB2 in various tissues of female and male mice with much higher expression in reproductive organs [5]

The present study on male albino rats demonstrated a significant reduction in serum levels of Nesfatin- 1 after orchidectomy that was reversed after testosterone replacement. Additionally, significant positive correlations were found between serum levels of Nesfatin-1 and testosterone in ORX and T-treated ORX groups.

Consistent with our finding, Senin et al., reported that testosterone can stimulate NUCB2/Nesfatin1 production at both gastric and adipose levels based on their finding that surgical orchidectomy provoked a decrease in the amount of NUCB2 protein content and mRNA levels in rat gastric mucosa, the NUCB2 protein storage in the subcutaneous adipose tissue, and the plasma NUCB2/ Nesfatin-1 levels; that were reversed after testosterone replacement. Additionally, they reported that circulating Nesfatin- 1 levels were correlated positively with plasma testosterone concentrations at the different ages in male rats [24]; a finding that is compatible with our finding in the present study. Additionally, Hatef \& Unniappan found that the expression of NUCB 2 mRNA and protein was increased in cultured hypothalamic and pituitary cells of mice in vitro treated with testosterone [25] Also, the study by Seon et al., demonstrated the reduction of NUCB2 mRNA expression level in the pituitary gland of orchidectomized mice, which increased after testosterone replacement; while, the expression level was significantly reduced after testosterone replacement in the hypothalamus [26] In contrast to the previous studies, the study by Bertucci et al., demonstrated the decrease in the expression of NUCB2 in the gut and pituitary gland of goldfish treated with testosterone [27]

The present study detected insignificant correlation between serum levels of Nesfatin- 1 and LH in all groups. We did not find in the literature studies that demonstrate the relationship between serum levels of Nesfatin-1 and LH; but some studies demonstrated the effect of gonadotropin injection on Nesfatin-1 expression levels. The study by Kim and Yang revealed that the expression levels of Nesfatin- 1 in the testis and epididymis were increased after gonadotropin injections and suggested that Nesfatin-1 produced in the male reproductive system might be regulated by gonadotropin secreted by the pituitary gland [28]. Additionally, the study by García-Galiano et al., showed that NUCB2/ Nesfatin-1 expression was up-regulated by pituitary LH [10]

Regarding the female albino rats, the present study found a significant decrease in serum levels of Nesfatin-1 after ovariectomy that was reversed after replacement with estradiol, progesterone or both. The effect of estradiol replacement on serum levels of Nesfatin-1 was more significant than that 
of progesterone, while the effect of combination of both hormones was insignificantly different from that of estradiol alone. Nesfatin-1 positively correlated with serum levels of and estradiol and progesterone in all female groups apart from control group. The present study suggested that the increase in serum levels of Nesfatin-1 after replacement with estradiol and progesterone may be attributed to the increased expression of Nesfatin- 1 mRNA in the pituitary gland and/or reproductive organs; and subsequently the increase in Nesfatin-1 protein that might be transported through the blood stream causing the increase in serum levels.

Consistent with our suggestion, the study by Kim et al., showed that Nesfatin-1/NUCB2 expression in the uterus was regulated by estrogen as its expression levels were significantly increased in the ovariectomized mice treated with 17 (3-estradiol [13]. Furthermore, the study by Chung et al., suggested that NUCB2 mRNA expression in the pituitary gland was upregulated by $17 / 3$-estradiol based on the finding that NUCB2 mRNA expression was decreased in the pituitary gland after ovariectomy and significantly increased with $17 / 3$-estradiol and progesterone injection [21]. Additionally, Hatef and Unniappan found that the expression of NUCB2 mRNA and protein was increased in cultured pituitary cells of mice in vitro treated with $17(\beta$-estradiol $[21,25]$.

In contrast to the previous studies, it was demonstrated that the expression of NUCB2 in the gut and pituitary gland was decreased in goldfish treated with estradiol [27]. Also, it was reported that the expression of NUCB2 mRNA in the cultured pituitary tissues of mice was significantly decreased with progesterone and also with combined progesterone and estradiol [21].

Several studies demonstrated that Nesfatin- 1 was expressed in many hypothalamic areas which are involved in the central regulation of pituitary hormones secretion $[\mathbf{1 5 , 2 9 , 3 0 ]}$. Moreover, the study by Chung et al., revealed that the expression of NUCB 2 mRNA and Nesfatin-1 protein was higher in the pituitary gland than in other organs and was localized in many cells in the anterior pituitary gland [21] . The relationship between Nesfatin-1 and LH is still a matter of controversy. The present study did not find any significant correlation between serum levels of Nesfatin-1 and LH in all female groups. Consistent with our finding, Çatlı et al. did not find any correlation between Nesfatin1 and basal LH or basal Follicle Stimulating Hormone (FSH) [31]. Additionally, it was demonstrated that exogenous administration of Nesfatin-1 did not cause any significant change in the circulating levels of gonadotropins in adult cyclic female rats [9].

In contrast, the study by Gonzalez et al., demonstrated that a single intraperitoneal injection of synthetic goldfish Nesfatin-1 resulted in an acute decrease in the expression of hypothalamic $\mathrm{GnRH}$ and serum LH levels. The authors reported that Nesfatin-1 had a predominant suppressive effect on reproduction through actions on the hypothalamo-pitutary gonadal axis of fish. This suppressive effect was suggested to be due to the down regulation of GnRH and/or by the direct action of Nesfatin-1 [15].

However, intracerebroventricular injections of Nesfatin-1 was reported to induce significant elevations in circulating LH levels, and central injections of anti-NUCB2 (morpholino-oligonucleotides) reduced circulating LH levels in pubertal female rats [9].

\section{In Conclusion:}

From the above discussion, it can be concluded that there is a sex difference in serum Nesfatin-1 levels between adult male and female albino rats with more significant level in female rats. Serum levels of Nesfatin-1 in rats are dependent on gonads and regulated by gonadal hormones. Serum levels of Nesfatin-1 are regulated by testosterone hormone in adult male albino rats and by estradiol and progesterone hormones in adult female albino rats where the effect of estradiol is more prominent than progesterone.

\section{Recommendations:}

Further studies are required to clarify the interrelationship between Nesfatin-1 and gonadal functions in both males and females and also, the potential pathophysiological role of disturbed Nesfatin-1 signaling in different reproductive disorders.

\section{References}

1- OH-I S., SHIMIZU H., SATOH T., OKADA S., ADACHI S., INOUE K., EGUCHI H., YAMAMOTO M., IMAKI T., HASHIMOTO K., TSUCHIYA T., MONDEN T., HORIGUCHI K., YAMADA M. and MORI M.: Identification of nesfatin- 1 as a satiety molecule in the hypothalamus. Nature, 443: 709-12, 2006.

2- GONZALEZ R., PERRY R. L., GAO X., GAIDHU M.P., TSUSHIMA R.G., CEDDIA R.B. and UNNIAPPAN S.: Nutrient responsive Nesfatin-1 regulates energy balance and induces glucose-stimulated insulin secretion in rats. Endocrinology, 152: 3628-37, 2011. 
3- STENGEL A. and TACHÉ Y.: Interaction between gastric and upper small intestinal hormones in the regulation of hunger and satiety ghrelin and cholecystokinin take the central stage. Curr. Protein Pept. Sci., 12: 293-304, 2011.

4- STENGEL A. and TACHÉ Y.: Gastric peptides and their regulation of hunger and satiety. Curr. Gastroenterol. Rep., 14: 480-8, 2012.

5- KIM J., CHUNG Y., KIM H., IM E., LEE H. and YANG H.: The Tissue Distribution of Nesfatin-1/NUCB2 in Mouse. Dev. Reprod., 18 (4): 301-9, 2014.

6- RAMANJANEYA M., CHEN J., BROWN J.E., TRIPATHI G., HALLSCHMID M., PATEL S., KERN W., HILLHOUSE E.W., LEHNERT H., TAN B.K. and RANDEVA H.S.: Identification of Nesfatin-1 in human and murine adipose tissue: A novel depot specific adipokine with increased levels in obesity. Endocrinology, 80: 3151-69, 2010.

7- ANGELONE T., FILICE E., PASQUA T., AMODIO N., GALLUCCIO M., MONTESANTI G., QUINTIERI A.M. and CERRA M.C.: Nesfatin-1 as a novel cardiac peptide: Identification, functional characterization, and protection against ischemia/reperfusion injury. Cell Mol. Life Sci., 70 (3): 495-509, 2013

8- STENGEL A. and TACHÉ Y.: Role of NUCB2/Nesfatin1 in the hypothalamic control of energy homeostasis. Horm. Metab. Res., 45 (13): 975-9, 2013.

9- GARCÍA-GALIANO D., NAVARRO V.M., ROA J., RUIZ-PINO F., SÁNCHEZ-GARRIDO M.A., PINEDA R., CASTELLANO J.M., ROMERO M., AGUILAR E., GAYTÁN F., DIÉGUEZ C., PINILLA L. and TENASEMPERE M.: The Anorexigenic Neuropeptide, Nesfatin1 , Is Indispensable for Normal Puberty Onset in the Female Rat. J. Neurosci., 30 (23): 7783-92, 2010.

10- GARCÍA-GALIANO D., PINEDA R., ILHAN T., CASTELLANO J.M., RUIZ-PINO F., SÁNCHEZ-GARRIDO M.A., VAZQUEZ M.J., SANGIAO-ALVARELLOS S. and ROMERO-RUIZ A.: Cellular distribution, regulated expression, and functional role of the anorexigenic peptide, NUCB2/nesfatin-1, in the testis. Endocrinology, 153 (4): 1959-71, 2012.

11- KIM J.H., KIM H.S., KIM S.M., YANG H.J., CHO H.H., HWANG S.P., MOON C.I. and YANG H.W.: Expression of nesfatin-1/NUCB2 and its binding site in mouse testis and epididymis. Dev. Reprod., 15: 249-56, 2011 a.

12- KIM J.H., YOUN M.R., BANG S.Y., SIM J.Y., KANG H.R. and YANG H.W.: Expression of Nesfatin-1/NUCB2 and its binding site in mouse ovary. Dev. Reprod., 14: 287-95, 2010 .

13- KIM J.H., LEE K.R., KIM H.K., NO S.H., YOO H.M., MOON C.I. and YANG H.W.: 17 beta-estradiol regulates the expression of Nesfatin-1/Nucb2 in mouse uterus. Dev. Reprod., 15: 349-57, $2011 \mathrm{~b}$.

14- GARCÍA-GALIANO D. and TENA-SEMPERE M.: Emerging Roles of NUCB2/Nesfatin-1 in the Metabolic Control of Reproduction. Bentham science, 19: 6966-72, 2013.

15- GONZALEZ R., SHEPPERD E., THIRUPPUGAZH V., LOHAN S., GREY C., CHANG J.P. and UNNIAPPAN
S.: Nesfatin-1 Regulates the Hypothalamo-PituitaryOvarian Axis of Fish. Biol. Reprod., 4: 87-4, 2012.

16- WATANOBE H. and YONEDA M.: A mechanism underlying the sexually dimorphic ACTH response to lipopolysaccharide in rats: Sex steroid modulation of cytokine binding sites in the hypothalamus. J. Physiol., 547 (1): 221-32, 2003

17- MOURA M.J. and MARCONDES F.K.: Influence of estradiol and progesterone on the sensitivity of rat thoracic aorta to noradrenaline. Life Sciences, 68: 881-8, 2001.

18- MARCONDES F.K., BIANCHI F.J. and TANNO A.P.: determination of the estrous cycle phases of rats: Some helpful considerations. Braz. J. Biol., 62 (4A): 609-14, 2002.

19- FERNÁNDEZ-GUASTI A. and MARTÍNEZ-MOTA L.: Orchidectomy sensitizes male rats to the action of diazepam on burying behavior latency: Role of testosterone. Pharmacol. Biochem. Behav., 75: 473-9, 2003.

20- IRAHARA M., TAMURA T., MATUZAKI T., SAITO S. YASUI T., YAMANO S., KAMADA M. and AONO T.: Orexin-A suppresses the pulsatile secretion of luteinizing hormone via 1 -endorphin. Biochem. Biophys. Res. Commun., 281: 232-6, 2001.

21- CHUNG Y., KIM J., IM E., KIM H. and YANG H.: Progesterone and $17(3$-estradiol regulate expression of Nesfatin-1/NUCB2 in mouse pituitary gland. Peptides, 63 C: 4-9, 2015.

22- TIETZ N.W.: Clinical Guide to Laboratory Tests, ${ }^{3 \mathrm{rd}}$ Ed., W.B. Saunders Company, Philadelphia, 509-80, 1995.

23- HOFMANN T., ELBELT U., AHNIS A., ROSE M., KLAPP B.F. and STENGEL A.: Sex-specific regulation of NUCB2/Nesfatin-1: Differential implication in anxiety in obese men and women. Psychoneuroendocrinology, 60: 130-7, 2015.

24- SENIN L.L., AL-MASSADI O., BARJA-FERNANDEZ S., FOLGUEIRA C., CASTELAO C., TOVAR S.A., LEIS R., LAGO F., BALTAR J., BAAMONDE I., DIEGUEZ C., CASANUEVA F.F. and SEOANE L.M.: Regulation of NUCB2/Nesfatin-1 production in rat's stomach and adipose tissue is dependent on age, testosterone levels and lactating status. Mol. Cell. Endocrinol., 411: 105-12, 2015.

25- HATEF A. and UNNIAPPAN S.: Gonadotropin-releasing hormone, kisspeptin, and gonadal steroids directly modulate nucleobindin-2/Nesfatin-1 in murine hypothalamic gonadotropin-releasing hormone neurons and gonadotropes. Biol. Reprod., 96 (3): 635-51, 2017.

26- SEON S., JEON D., KIM H., CHUNG Y., CHOI N. and YANG H.: Testosterone Regulates NUCB2 mRNA Expression in Male Mouse Hypothalamus and Pituitary Gland. Dev. Reprod., 21 (1): 71-8, 2017.

27- BERTUCCI J.I., BLANCO A.M., CANOSA L.F. and UNNIAPPAN S.: Estradiol and testosterone modulate the tissue-specific expression of ghrelin, ghs-r, goat and nucb2 in goldfish. Gen. Comp. Endocrinol., 228: 17-23, 2016.

28- KIM J. and YANG H.: Nesfatin-1 as a New Potent Regulator in Reproductive System. Dev. Reprod., 16 (4): 253 64, 2012. 
29- PINILLA L., AGUILAR E., DIEGUEZ C., MILLAR R.P and TENA-SEMPERE M.: Kisspeptins and reproduction: Physiological roles and regulatory mechanisms. Physiol. Rev., 92 (3): 1235-316, 2012

30- ELIAS C.F. and PUROHIT D.: Leptin signaling and circuits in puberty and fertility. Cell. Mol. Life Sci., 70 (5): 841-62, 2013.

31- ÇATLI G., ANIK A., KÜME T., ÇALAN Ö.G., DÜNDAR B.N., BÖBER E. and ABACI A.: Serum Nesfatin-1 and leptin levels in non-obese girls with premature thelarche. J. Endocrinol. Invest., 38 (8): 909-13, 2015.

\section{تآثير الهرمونات الجنسية على مستويات النيسفاتين-1 فى مصل الدم في جمرذان التجارب}

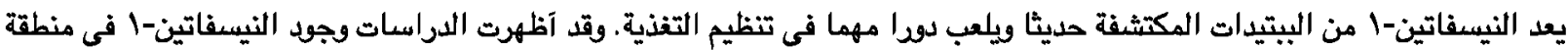

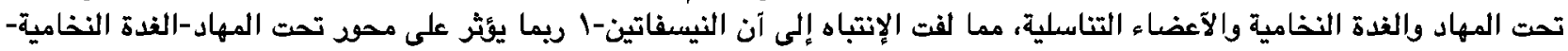

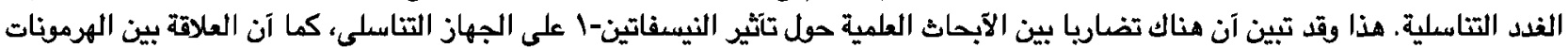

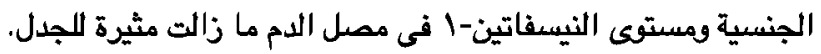

وقد صممت هذه الدراسة لبيان ما إذا كان هناك إختلاف فى مستوى النيسفاتين-1 بين ذكود وإناث الجرذان اليضاء البالغة، ولبيان العلاقة

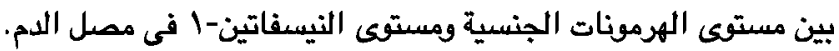

ولتحقيق ما سبق ذكره من آهداف فقد آجريت الدراسة على عدد \ل من ذكود الجرذان البيضاء البالغة وعدد ـب من إناث الجرذان اليضاء البالغة:

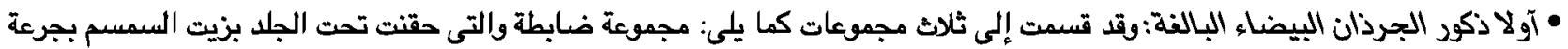

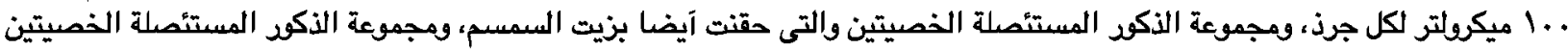

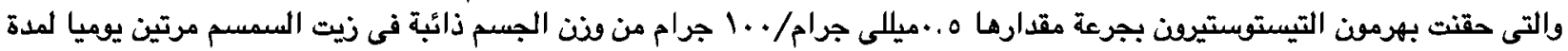
بآيام.

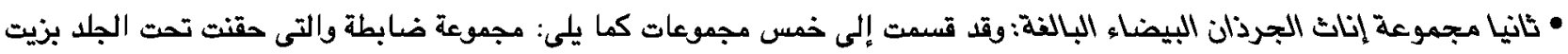

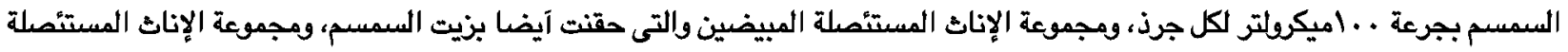

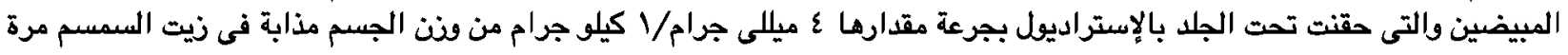

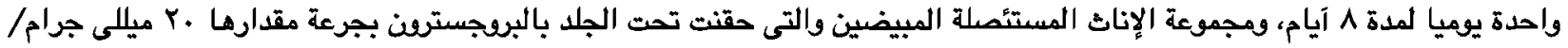

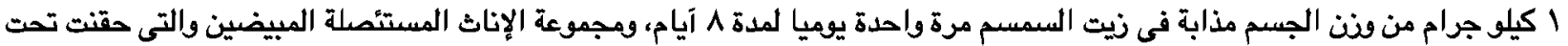

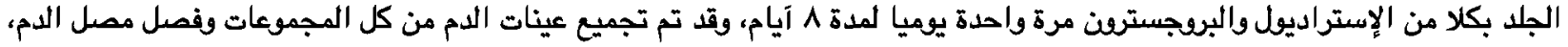

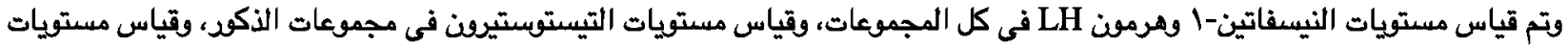
الإستراديول والبروجيسترون في مجموعات الإناث.

وقد آتمر هذا البحث عن العديد من النتائج وهى:

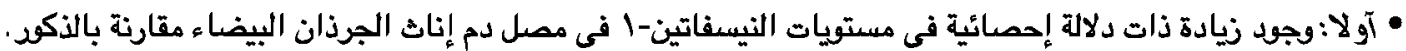

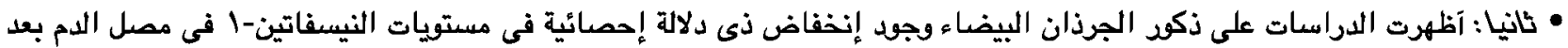

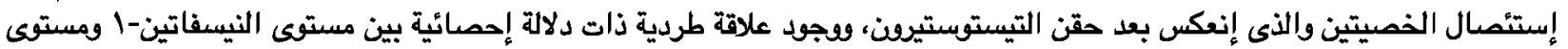

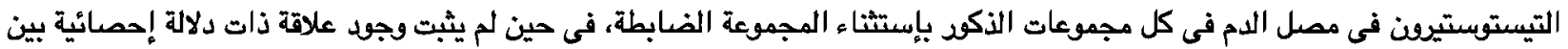
مستويات النيسفاتين-1 ومستويات LH في مصل الئ الدم في كل مجموعات الذكود.

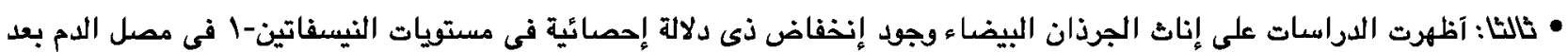

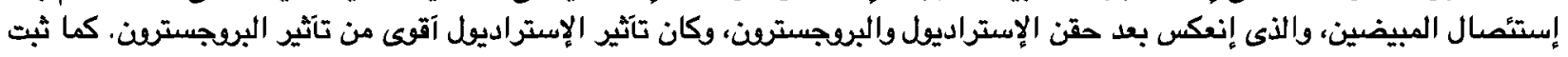

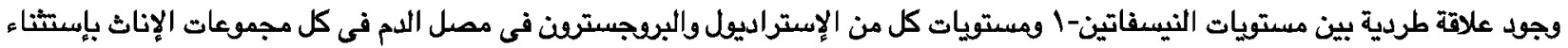

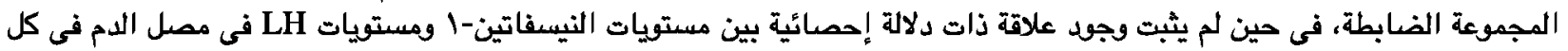
مجموعات الإناث.

ونستتج من هذه الدراسة: آن الهرمونات الجنسية تلعب دودا هاما فى تنظيم مستويات النيسفاتين-1 فى مصل دم الجرذان البيضاء 